\title{
MANFAAT PENGGUNAAN MEDIA YOUTUBE TERHADAP PERKEMBANGAN ANAK SEKOLAH DASAR DI ASRAMA SPN CISARUA BANDUNG BARAT
}

\author{
Iqbal Rediansyah \\ IKIP Siliwangi - Cimahi - Jawa Barat \\ rediansyahiqbal37@gmail.com
}

Received: Juni, 2020; Accepted: September, 2020

\begin{abstract}
this research is based on background. As we see now many children who know more about youtube such as YouTube content that are popular with children namely online game tutorials, vloger content that is being hit on YouTube, see foreign music bands that are currently being hit are boy bands or girl bands from korea that is on the gadgets or computers respectively. This study aims to determine the process of managing YouTube media in knowledge and behavior towards children at an early age from 6 to 12 years. The theory used in this research is the PLS concept, Youtube. The researcher formulated The researcher formulated three questions 1. To find out the use of YouTube social media in early childhood in the SPN Cisarua Dormitory, 2. To find out the role of parents in managing YouTube's social media for children, 3. To see children's responses to the use of YouTube social media. YouTube media management in West Bandung Cisarua Dormitory in this study researchers used a quantitative approach. Data collected through interviews, observation and documentation. As for the population of this study yatu children who are housed in the Cisarua West Bandung Dormitory. The results of this study most children know about YouTube just for their pleasure and become their passion because every time they play more gadgets than playing outside.
\end{abstract}

Keywords: youtube, non-formal education

\begin{abstract}
Abstrak
penelitian ini dilandasi oleh latar belakang. Seperti yang kita lihat sekarang banyak anak-anak yang lebih mengetahui tentang youtube seperti konten youtube yang digemari anak-anak yaitu tutorial game online, konten vloger yang sedang hits di youtube, melihat band musik luar negeri yang sekarang sedang hits itu boy band ataupun girl band dari korea yang ada di gadget atau komputer masing masing. penelitian ini betujuan untuk mengetahui proses pengelolaan media youtube dalam pengetahuan dan perilaku terhadap anak-anak pada usia dini dari 6 sampai 12 tahun. Teori yang digunakan dalam penelitian ini adalah konsep PLS, Youtube. peneliti merumuskan tiga pertanyaan 1. Untuk mengetahu penggunaan media sosial youtube di anak usia dini di asrama SPN cisarua,2. Untuk mengetahui peran orang tua terhdapa pengelolaan media sossial youtube untuk anak-anak, 3. Untuk melihat respon anakanak terhadap penggunaaan sosial media youtube. pengelolaan media youtube di Asrama Cisarua Bandung Barat dalam penelitian ini peneliti menggunakan menggunakan pendekatan kuantitatif. Data dikumpulkan melalui wawancara, observasi dan dokumentasi. Adapun yang menjadi populasi penelitian ini yatu anak-anak yang bertempat di Asrama Cisarua Bandung Barat. Hasil dari penelitian ini anak-anak kebanyakan mengetahui tentang youtube itu hanya untuk kesenangan mereka dan menjadi kegemaran mereka karena disetiap waktunya mereka lebih banyak bermain gadget dibandingkan bermain diluar.
\end{abstract}

Kata Kunci: youtube, pendidikan luar sekolah

How to Cite: Rediansyah, I. (2020). Manfaat Penggunaan Media Youtube Terhadap Perkembangan Anak Sekolah Dasar Di Asrama SPN Cisarua Bandung Barat. Comm-Edu (Community Education Journal) 3 (3), 315-319. 


\section{PENDAHULUAN}

Dijaman yang semakin modern seperti sekarang ini, seperti yang kita lihat sekarang banyak anak-anak mengetahui tentang permainan online atau yang ada di gaget masing masing. Dengan seiring perkembangan zaman yang sangat canggih memanfaatkan media youtube untuk pengetahuan dan perilaku kepada anak-anak.

Perkembangan kebudayaan yang ada pada manusia adalah dimana proses kualitatif yang mengacu kepada fungsi sosial dan psikologis untuk penyempurnaan diri seseorang yang akan berlangsung sepanjang hidupnya. Perkembangan anak pada usia dini disebut senagai masa emas "Golden Age" dimana yang diartikan dimana perkembangan ini sangat berpengaruh terhadap perkembangan yang akan datang pada anak tersebut. Usia sampai 6 tahun, dimana usia ini sangat menentukan dalam pembentukan karakter, contohnya : sikap, perilaku, dan kepribadian seseorang. Ada beberapa faktor yang mempengaruhi pertumbuhan dan perkembangan anak baik faktor dari keluarga, pendidikan orang tua, dan jaman yang semakin modern. (Wulandari, 2016)

Awal mula media internet muncul didunia pada abad 21, pada abad ini dimana semua berubah sangat begitu pesat contohnya informasi dan teknologi yang bisa diakses melalui internet. Dengan ini perkembangan informasi dan teknologi, mengikuti akan perubahan jaman yang akan pada jaman sekarang. Perkembangan ini juga mengaruhi perkembangan anak dan budaya yang ada di masyarakat. Disuatu daerah atau negara, terdapat 143, 46 juta jiwa yang menggunakan jasa internet, sedangkan didunia 6,5 milyar pada tahun 2005. Populasi didunia akan berkembang dan perkembangan pula jasa internet didunia. Sedangkan pada tahun 2017 sebanyak 7,4 milyar orang yang menggunakan media internet. Terjadi peningkatan begitu pesat menjadi $48 \%$. Kita lihat dari dua sisi negara ada negara berkembang dan negara maju (APJII, 2019)

Youtube yaitu sebuah sosial media untuk mempublikasikan video, media ini dapat diakses oleh semua orang di negara manapun. Media ini resmi berdiri pada tahun 2005. Pendirinya yaitu Chad Hurley, Steve Chen, Jawed Karim, mereka bertiga ini adalah mantan karyawan PayPal. Kemudian media Youtube dibeli oleh Google dan diperkenalkan kembali tahun 2006. Berdasarkan riset yang dilakukan oleh hootsuite, jelas bahwa Youtube sangat digemari oleh masyarakat Indonesia, dengan memasuki peringkat most active social media. Youtube memudahkan miliyaran orang dalam menemukan, menonton, dan membagikan berbagai macam video. Youtube menyediakan forum bagi orang-orang untuk saling berhubungan, memberikan informasi, menginspirasi orang lain di seluruh dunia, serta bisa sebagai pembuat konten dan pengiklan, baik yang besar maupun kecil. Youtube menjadi pemimpin untuk situs pencarian video di internet, dengan lebih dari 1.000.000.000 video ditonton oleh pengunjung setiap harinya. Lebih dari 75.000 video kini diunggah setiap hari ke Youtube. (Putra, 2018). Penelitian ini bertujuan untuk melihat perkembangan anak dan untuk mengembalikan kembali tentang terkait perkembangan di tengah jaman modern seperti ini. Tugas kita adalah bagaimana cara kita mengembalikan perkembangan anak melalui media youtube di SPN cisarua.

\section{LANDASAN TEORI}

Menurut Soelaman Joesoef, pendidikan non formal adalah setiap kesempatan dimana terdapat komunikasi yang terarah di luar sekolah dan seseorang memperoleh informasi, pengetahuan, latihan maupun bimbingan sesuai dengan tingkat usia dan kebutuhan hidup, dengan tujuan mengembangkan tingkat keterampilan, sikap dan nilai-nilai yang memungkinkan baginya 
menjadi peserta-peserta yang efesien dan efektif dalam lingkungan keluarga, pekerjaan bahkan lingkungan masyarakat dan negaranya. Dari beberapa definisi diatas dapat disimpulkan bahwa pendidikan non formal adalah pendidikan kegiatan belajar mengajar yang diadakan di luar sekolah untuk memenuhi kebutuhan pendidikan peserta didik tertentu untuk mendapatkan informasi, pengetahuan, latihan, dan bimbingan sehingga mampu bermanfaat bagi keluarga, masyarakat, dan negara. (Soelaman, 1992)

UUD no 20 tahun 2003 BAB VI bagian kelima Pasal 26 ayat"Pendidikan (1) "nonformal diselenggarakan bagi warga masyarakat yang memerlukan layanan pendidikan yang berfungsi sebagai pengganti, penambah, dan/atau pelengkap pendidikan formal dalam rangka mendukung pendidikan sepanjang hayat"

\section{Youtube}

Youtube yaitu sebuah sosial media untuk mempublikasikan video, media ini dapat diakses oleh semua orang di negara manapun. Media ini resmi berdiri pada tahun 2005. Pendirinya yaitu Chad Hurley, Steve Chen, Jawed Karim, mereka bertiga ini adalah mantan karyawan PayPal. Kemudian media Youtube dibeli oleh Google dan diperkenalkan kembali tahun 2006. Berdasarkan riset yang dilakukan oleh hootsuite, jelas bahwa Youtube sangat digemari oleh masyarakat Indonesia, dengan memasuki peringkat most active social media. Youtube sangat memudahkan masyarakat untuk menonton dan membagikan vidio yang untuk ditonton oleh masyarakat atau orang. (Putra, 2018).

\section{METODE}

Dalam penelitian, peneliti menggunakan metode deskriftif dengan pendekatan kualitatif. Dimana kualitatif adalah salah satu kegiatan penelitian untuk mencari data dari subjek yang akan diteliti yang berdasarkan pada metodologi yang dikhususkan menyelidiki suatu kejadian fenomena sosial dan permasalahan-permasalahan yang ada pada masyarakat yang mendapatkan data yang akurat dan relefan. (Hamid, 2013)

Pada pendekatan ini peneliti menggambarkan atau menceritakan suatu kejadian dan peneliti membuat laporan dari hasil responden objek yang diteliti dan selanjutnya, peneliti melakukan studi kasus secara ilmiah maupun alami. Penelitian kualitaif biasanya akan membahas hasil yang membesar atau latar alamiah. Biasanya teknik ini menggunakan objek yaitu manusia untuk diteliti. Pengertian kualitatif lebih mementingkan proses dari pada hasil.

Peneliti akan menggunakan teknik dalam mengumpulkan data dengan wawancara, dokumentasi, dan catatan lapangan. Alasan peneliti menggunakan teknik wawancara yaitu untuk mengumpulkan data-data yang ada pada objek penelitian guna hasil informasi yang lebih akurat dan nyata. Dengan adanya dokumentasi, hasil selama dilakukannya penelitian itu ada dan berupa catatan lapangan, selama proses penelitian, kita menulis hasil perkembangan selama jalannya penelitian. Penelitian akan dilakukan di Jl. Kolonel Masturi no. 110, Asrama SPN Cisarua Polda Jabar, Ds. Jambudipa, Kec. Cisarua, Kab. Bandung Barat. Populasi yang digunakan dalam penelitian ini baik berupa subjek atau objek adalah populasi anak-anak, dan orang tua. Peneliti akan mengambil subjek atau objek 4 anak-anak dan 4 orang tua.

Menurut (Moleong, 2013) terdapat 3 langkah-langkah untuk melakukan penelitian meliputi:

1. Tahap Lapangan : tahap ini merupakan langkah awal yang harus dilakukan oleh peneliti yang harus membuat rancangan usulan penelitian hingga menyiapkan perlengkapan untuk 
penelitian. Dalam tahapan ini peneliti harus memahami latar belakang yang ada pada masyarakat dengan persiapan-persiapan yang mantap untuk masuk ke lapangan penelitian.

2. Tahap pekerja lapangan : tahap ini biasanya peneliti mempersiapkan diri untuk mencari dan mengumpulkan data-data yang akan dibuat analisis data. Dalam peneliti memilih narasumber objek penelitian baik wawancara maupun lainnya. Dan pengelolaan dokumentasi adalah salah satu bukti kerja wawancara terhadap objek yang diteliti.

3. Tahap analisis data : tahap ini biasanya peneliti akan mengolah data yang sudah dikumpulkan atau diperoleh dari narasumber maupun dokumen lainnya. Kemudian akan dijadikan atau disusun kedalam sumber penelitian.

\section{HASIL DAN PEMBAHASAN}

\section{Hasil}

Penerapan media youtube di asrama SPN Cisarua anak-anak masih belum menggunakan media youtube atau memanfaatkan media youtube untuk perkembangan, melainkan media youtube dijadikan sutu hiburan untuk menonton v-log atau vidio yang tidak wajar mereka tonton.

Pengetahuan anak-anak terhadap Youtube di asrama SPN Cisarua. Berdasarkan hasil wawancara kepada anak-anak sebagian dari merek hanya menggunakan Youtube untuk melihat tutorial game dan menonton tutorial Youtubers yang lagi trend. Bukan digunakan dalam pembelajaran untuk perkembangan diri atau pengetahuan.

Proses memperkenalkan Youtube. selama tiga minggu berturut-turut anak-anak menonton vidio yang sudah dipilih oleh peneliti yang akan ditonton oleh anak-anak menggunakan media youtube untuk mendapatkan ilmu yang bermanfaat dan merubah perilaku mereka yang sudah disediakan oleh peneliti. dan setelah menonton selanjutnya peneliti turun kelapangan untuk melihat hasil perkembangan ilmu dan perilaku anak-anak selama menonton Youtube.

Adapun hasil dari wawancara kepada sala satu subjek yang diwawancarai, ibu imas usai 36 th, pkerjaan IRT. Bahwa sebelum anak-anak menggunakan media youtube hanya untuk sekedar hiburan semata tanpa tahu dampak baik atau negatif dari menggunakan media youtube. dan setelah adanya penelitian yang dilaukan oleh peneliti setelah memperkenalkan kegunaan media youtube kepada anak-anak sebagai salah satu cara untuk mendapatkan pengetahuan baik dibidang pendidikan atau pun yang lainnya. Dan para ibuibu juga lebih mengawasi anak-anak dalm menggunakan media youtube.

Berdasarkan hasil wawancara dan angket hasilnya anak-anak dapat menggunakan media youtube atau memanfaatkan media Youtube untuk pengetahuan dan perilaku yang lebih baik dan menambah ilmu lebih banyak lagi, dan menonton vidio yang sewajarnya mereka tonton atau vidio tentang dunia pendidikan.

\section{Pembahasan}

Penerapan media youtube asrama SPN Cisarua anak-anak masih banyak yang belum manfaat baik tentang youtube. Pengetahuan anak-anak terhadap Youtube di asrama SPN Cisarua. Berdasarkan hasil wawancara kepada anak-anak sebagian mengetahui Youtube untuk melihat tutorial game dan menonton tutorial Youtubers yang lagi trend. Peranan orang tua sangat penting dalam mengontrol tayangan youtube yang ditonton oleh anak-anaknya. Orang tua perlu mendampingi anak - anak saat nonton, memberikan pemahaman tentang suatu tayangan di yang sedang disaksikan. Hal ini perlu karena bisa sekaligus untuk membangun sarana komunikasi dengan anak, dan mengurangi dampak negatif dari tayangan youtube bagi anak- 
anak, seperti yang kita ketahui pada saat ini Youtube menjadi pemimpin untuk situs pencarian video di internet, dengan lebih dari 1.000.000.000 video ditonton oleh pengunjung setiap harinya. Setiap hari youtube mengunggah vidio lebih dari 1.000.000.' (Putra, 2018)

Proses memperkenalkan Youtube. selama tiga minggu berturut-turut anak-anak menonton menggunakan media youtube untuk mendapatkan ilmu yang bermanfaat dan merubah perilaku mereka yang sudah menonton video yang sudah disediakan oleh peneliti, dan setelah menonton selanjutnya peneliti turun kelapangan untuk melihat hasil perkembangan ilmu dan perilaku anak-anak selama menonton Youtube. Jika anak-anak memanfaatkan dengan baik, tentu dengan berbekal gawai dan kuota internet, mereka bisa mencari apa saja di Youtube. Misalkan, ketika anak-anak sedang kesulitan mengerjakan tugas matematika, mereka tinggal mengakses bagaimana cara menyelesaikan dengan bantuan penjelasan dari si pembuat video tersebut. Mereka tak perlu pergi meninggalkan rumah, mencari guru privat, atau mencari teman yang lebih pandai untuk menyelesaikan pekerjaan rumah tersebut. Dalam proses memenfaatkan media youtube untuk anak-anak perlu juga bantuan dari orang tua untuk memantau atau memastikan vidio yang mereka tonton.

Berdasarkan hasil wawancara dan angket hasilnya anak-anak dalam memanfaatkan media Youtube untuk pengetahuan dan perilaku yang lebih baik dan menambah ilmu lebih banyak lagi di tingkat anak-anak usia dini di lingkungan SPN cisarua, dan respon anak-anak terhadap peneliti untuk memberikan ilmu tentang media youtube untuk perkembangan mereka sangat baik dan bisa mengikuti jadwal yang sudah di rencanakan oleh peneliti, dan peran orang tua untuk membantu dalam menggunakan media youtube untuk perkembangan anak sangat mendukung dan merespon dengan baik untuk membantu memilih vidio yang sewajarnya merea tonton.

\section{KESIMPULAN}

Dari hasil penelitian dan pembahsan peneliti dapat menarik kesimpulan terkaita tujuan yang diteliti bahwa media youtube untuk membantu perkembangan anak-anak cukup bermanfaat dalam hal yang positif bagi mereka dan peran orng tua pun sangant dibutuhkan dalam memebantu dalam hali ini baik membantu dalam memilih vidio untuk di tonton anak-anak maupun hal-hal yang lain.

\section{DAFTAR PUSTAKA}

APJII. (2019). Asosiasi penyelenggara jasa internet indonesia. Jakarta: Buletin APJI.

Hamid, D. (2013). Metode Penelitian Pendidikan dan Sosial. Bandung: Alfabeta.

Moleong, L. (2013). Metodologi Penelitian Kualitatif. Edisi Revisi . Bandung: Remaja Rosdakarya.

Putra, A. (2018). Pengaruh Youtube Di Smartphone Terhadap Perkembangan Komunikasi Interpersonal Anak. Jurnal Penelitian Komunikasi, 161-162.

Soelaman, J. (1992). Pendidikan non formal Di dalam Sistem Pendidikan dan Pembangunan Nasional. Jakarta: Bumi Aksara.

Wulandari, R. (2016). Perbedaan Perkembangan SOSIAL Anak usia 3 - 6 tahun dengan pendidikan usia dini dan tanpa usia dini di kecamatan peterong jombang. Biomedika, 4748 . 